\title{
THE ROLE OF ACCOUNTANT IN ESTONIAN ENTERPRISE: SURVEY OF STUDENTS OPINION
}

\author{
Monika Nikitina-Kalamäe \\ Tallinn University of Technology \\ Natalja Gurvitch \\ Tallinn University of Technology
}

\begin{abstract}
Major events and changes in the economic world during last decades have generated a growing public interest towards accounting in general and accountants in particular, which goes in line with the increasing role of professions in the society. The aim of the research is to reveal students' opinion on the functions and role of accountants in modern enterprise and to figure out what personal characteristics, knowledge and skills should be an inevitable attribute of the modern accounting profession. Findings confirmed that in Estonia accountant is regarded as a person preparing various tasks for the management in order to assist them in the decision-making process and sometimes giving valuable advice before the decision is made. It can be stated that results clearly outline the demand of high education programmes with accounting specialization in Estonia with the curriculum corresponding to the rapid changes in the modern world. This paper also highlights the importance of various knowledge, skills and personal characteristics as an essential combination for successful everyday work in the field of accounting. The findings also have practical implications for HEI developments targeting renewal, changes and amendments in the business and economics curriculum.
\end{abstract}

Keywords: accountant's competencies, accountant's tasks, accountant's responsibilities, accountant's role

JEL code: M41

\section{Introduction and literature review}

Major events and changes in the economic world during last decades have generated a growing public interest towards accounting in general and accountants in particular, which goes in line with the increasing role of professions in the society. According to Carter et al. (2015) "the great issues of our time become understood through a range of different forms of professional knowledge". Much has been argued about the role of accountant in the modern financial world in general and enterprise in particular (Ottoson, 2015), required competences, personal characteristics, knowledge, skills and education (Luts, 2016).

It is obvious that in the changing world the role of accountant is changing rapidly (Guthrie \& Parker, 2016). Numerous researchers outline that accounting has the important role in "reviving the economy" (Artene et al, 2015), developing the national economy (Yuan et al, 2015) and dealing with various problems of their clients (Carter et al, 2013). Furthermore, during last decades more and more researchers are of the opinion that accountant should also be involved in sustainability reporting (The Institute of Chartered Accountant...., 2016) related to social and environmental activities of the company like carbon accounting (Lovell \& Kenzie, 2011), water accounting etc. These developments have forced different professional and high educational institutions to incorporate sustainability issues into their curriculum, for example Institute of Chartered Accountants of Nigeria (ICAN) has followed this path and made significant changes in its curriculum of 2014 for professional students (Nwobu et al, 2015).

IFAC code of Ethics outlines that "a distinguishing mark of the accountancy profession is its acceptance of the responsibility to act in the public interest" (IFAC Code of Ethics). The Accountancy Profession is also recognized by IFAC as a "critical partner in many of the Sustainable Development Goals, including: quality education, decent work and economic 
growth, industry, innovation, and infrastructure, responsible consumption and production, climate action, peace, justice, and strong institutions and partnership for the goals" (IFAC, The Accountancy...., 2016). Today the accountant has become a "border guard" in serving public interests by providing reliable information about the performance of organization and also the contractual part they are hired to serve Davenport \& Dellaportas (2009). However, this not the "one and only" responsibility. There is an emerging worldwide trend to prepare accountants for finance leadership roles, which in turn broadens the range of responsibilities and requires additional knowledge, skills and experience. The findings of Spraakman et al (2015) reveal that the role of accountant today has shifted from journalizing business transactions to also analysing various business issues, which in turn requires additional knowledge and skills.

Within the contemporary research about accountant ads a profession, the following trends are widely discussed:

(i) role and functions of the accountant in a society and modern enterprise (Albu et al, 2011 Carter et al, 2015), and (ii) relation of personal characteristics, knowledge and skills to the everyday work of the accountant and professional commitment (Gendron et al, 2009, Chan et al, 2008, Clayton \& van Staden, 2015).

These developments have influenced the present research and inspired authors to investigate the current situation in Estonia.

The remainder of this paper is organized as follows. After the linkage of the selected topic to the current literature, authors provide a practical insight into the role of accountant in Estonian enterprise. Furthermore, authors conduct a survey among students of Tallinn University of Technology to reveal their opinion. Results are taken as a basis for concluding remarks.

\section{Methodology}

The authors conducted a survey among graduate students specializing in Accounting in Tallinn University of Technology. The questionnaire consisted of 6 multiple-choice and yes/no questions. The survey took place in the period of 08.09-18.09.2016. In total there were distributed 85 questionnaires and 80 responses were collected. The results of the survey were interpreted using the Microsoft Excel, this information was than compiled and analysed. Table 1 shows the profile of the respondents.

Table 1. Demographic data of the respondents

\begin{tabular}{|l|r|}
\hline Parameter & Sample \\
\hline Age & 40 \\
\hline Younger than 25 & 32 \\
\hline $26-35$ & 8 \\
\hline 36 and older & 80 \\
\hline Total & \\
\hline Work experience & 58 \\
\hline $0-5$ years & 9 \\
\hline 6-10 years & 7 \\
\hline $11-15$ years & 6 \\
\hline 16 and more & 80 \\
\hline Total & 10 \\
\hline Status & 70 \\
\hline Bachelor student & 80 \\
\hline Master student & 77 \\
\hline Total & 3 \\
\hline Education & 80 \\
\hline Bachelor degree & \\
\hline Master degree & \\
\hline Total & \\
\hline
\end{tabular}

Data of Table 1 clearly demonstrates that most respondents are Master students with working experience less than 5 years. 


\section{Results}

The authors would like to present results of the survey by Tables 2-7. In authors opinion the selected questions are most challenging and worth discussion. Table 2 summarizes the opinion of respondents on the role of accountant in the modern Estonian enterprise.

Table 2. Role of accountant in the Estonian enterprise (the respondents were allowed to choose one option)

\begin{tabular}{|l|r|r|}
\hline Type of task & Number of responses & Responses in \% \\
\hline Accountant & 42 & 53 \\
\hline Accountant- counsellor to the board members & 17 & 21 \\
\hline Accountant-office assistant & 9 & 11 \\
\hline Accountant-financial manager & 8 & 10 \\
\hline Other & 4 & 5 \\
\hline
\end{tabular}

Source: authorial computation based on the survey results

Results brought up in Table 2 indicate that respondents mostly associate no additional tasks with the role of accountant in the Estonian company, however $21 \%$ of respondents are of the opinion that accountant should also give advice to the board members.

In the Table 3 there are listed statements regarding different tasks the accountant should fulfil in the course of everyday work.

Table 3. Tasks and responsibilities the accountant should fulfil during every day work (the respondents were allowed to choose several options)

\begin{tabular}{|l|r|r|}
\hline Type of task & Number of responses & Responses in \% \\
\hline Financial accounting & 79 & 99 \\
\hline Payroll accounting & 77 & 97 \\
\hline Taxation accounting & 77 & 97 \\
\hline External reporting & 74 & 93 \\
\hline Activities related to the management decision-making process & 18 & 23 \\
\hline Managerial accounting & 16 & 20 \\
\hline Social and environmental accounting & 9 & 11 \\
\hline Social and environmental reporting & 7 & 9 \\
\hline
\end{tabular}

Source: authorial computation based on the survey results

The data of the Table 3 clearly indicates that the most common tasks for the respondents seem the ones related to financial, payroll, taxation accounting and external reporting. Social and environmental accounting and reporting seem less common.

Table 4 represents the respondents' opinion regarding accountant competence and everyday working activities.

Table 4. Respondents' opinion on the selected statements in number of responses

\begin{tabular}{|c|c|c|c|}
\hline Statement & $\begin{array}{l}\text { Very } \\
\text { often }\end{array}$ & Sometimes & No \\
\hline $\begin{array}{l}\text { Accountant prepares documents/reports/calculations for the management in } \\
\text { order to assist them in the decision-making process }\end{array}$ & 36 & 37 & 7 \\
\hline $\begin{array}{l}\text { Members of the board ask accountant for an opinion before making the final } \\
\text { decision }\end{array}$ & 19 & 55 & 6 \\
\hline
\end{tabular}

Source: authorial computation based on the survey results

Results of the survey shown in the Table 4 clearly indicate that rather small amount of respondents - less than $10 \%$ stated that accountants should not be participating in decisionmaking process and never asked about their opinion before the management makes its final decision. Worth attention is the fact that only $24 \%$ of respondents indicated that members of the board very often ask accountant for the advice or opinion before making their decisions. Table 5 shows the respondents opinion on the required minimum level of the education required to work as an accountant. 
Table 5. Respondents' opinion on the minimum level of accountant's education (the respondents were allowed to choose one option)

\begin{tabular}{|l|r|r|}
\hline Type of education & Number of responses & Responses in \% \\
\hline Bachelor or Master degree in Accounting & 32 & 40 \\
\hline Professional higher education in Accounting & 27 & 34 \\
\hline Vocational school education & 16 & 20 \\
\hline Workshops and trainings in Accounting & 5 & 6 \\
\hline
\end{tabular}

Source: authorial computation based on the survey results

Authors it is very important that respondents outlined the importance of education for the accountant, as only less than $10 \%$ stated that workshops and training is and appropriate qualification, more than half of the respondents find it necessary to obtain either Bachelor or Master degree.

Table 6 illustrates which knowledge and skills in respondents' opinion are most demanded during every day work of the accountant in addition to knowledge of financial accounting.

Table 6. Knowledge and skills required by accountant in everyday work (the respondents were allowed to choose several options)

\begin{tabular}{|l|c|c|}
\hline Type of knowledge and skills & Number of responses & Responses in \% \\
\hline Knowledge of laws and legislations & 63 & 79 \\
\hline Financial management - related & 56 & 70 \\
\hline It-related & 54 & 68 \\
\hline Knowledge of foreign languages & 40 & 50 \\
\hline Personnel and staff related & 26 & 33 \\
\hline Assistant to management related & 16 & 20 \\
\hline Other & 4 & 5 \\
\hline
\end{tabular}

Source: authorial computation based on the survey results

Findings of the survey presented in Table 6 demonstrated that besides knowledge of financial accounting respondents consider most important knowledge of laws and legislations, ITrelated knowledge and also knowledge of foreign languages.

Table 7. Personal qualities and characteristics required by accountant in everyday work

\begin{tabular}{|l|r|r|}
\hline Qualities and characteristics & Number of responses & Responses in \% \\
\hline Accuracy & 74 & 93 \\
\hline Analytical skills and logic thinking & 73 & 93 \\
\hline Integrity & 73 & 91 \\
\hline Ability to resist work routine & 61 & 76 \\
\hline Ability to learn & 57 & 71 \\
\hline Responsibility & 54 & 68 \\
\hline Determination & 52 & 65 \\
\hline Ability to resist stress and pressure & 46 & 58 \\
\hline Decision-making and independence & 44 & 55 \\
\hline Cooperation skills & 41 & 51 \\
\hline Communication skills & 24 & 30 \\
\hline Creativity & 11 & 14 \\
\hline Management ability & 6 & 8 \\
\hline Risk Taking & 5 & 6 \\
\hline
\end{tabular}

Source: authorial computation based on the survey results

Table 7 summarizes the opinion of key personal characteristics and qualities of the accountant (the respondents were allowed to choose several options)

It is obvious that most required qualities and personal characteristics of the accountant are: accuracy, analytical skills and logic thinking, integrity, ability to resist work routine and ability to learn and the least demanded turned out to be creativity, management ability and risk taking. 


\section{Discussion and concluding comments}

The study examined the functions and role of the accountant in the modern Estonian enterprise and to figured out what personal characteristics, knowledge and skills are an inevitable attribute of the modern accounting profession. The findings of the survey confirmed that in Estonia accountant is regarded as a person preparing various types for the management in order to assist them in the decision-making process and sometimes giving valuable advice before the decision is made by the management. Survey also revealed that accounting job today requires various knowledge and skills and the accountant is associated with a highly educated person with good knowledge of information technologies, foreign languages, laws and legislation, routine prone, accurate, determined, ready and able to learn. In conclusion it can be stated that results of the survey clearly outline the demand of high education programmes with accounting specialization in Estonia with the curriculum corresponding to the rapid changes in the modern world. However, it should also be noted that results of the survey are not in line with the latest trends in the modern accounting that accountant should also deal with non-financial reporting and is regarded as a future financial leader of the company. That may be explained by the fact that most companies in Estonia are microenterprises with no requirement for such developments as was also commented by the respondents as largely depending on the type and size of company. Another important issue is that most of the respondents participated in the survey have quite short working experience less than 5 years, which narrows their perspective in regard to the further developments and major changes in the accounting profession.

This paper also highlights the importance of various knowledge, skills and personal characteristics as a combination for successful everyday work in the field of accounting. The findings also have practical implications for HEI developments targeting renewal, changes and amendments in the business and economics curriculum.

The authors are aware that the study has several limitations. The sample size of the survey is fairly small to make general conclusions valid for companies of all sizes. For the future research authors expect to broaden the scope and attract students specializing in different fields of economics, business and management.

\section{References}

Albu, C. N., Albu, N., Faff, R., Hodgson, A. (2011). Accounting Competencies and the Changing Role of Accountants in Emerging Economies: The Case of Romania. Accounting in Europe, vol. 8, no. 2, pp. 155-184.

Available at http://web.b.ebscohost.com/ehost/pdfviewer/pdfviewer?sid=8a3eb7a3-4cd941c4-b619-725aa1 (26.01.2016).

Artene, A. E., Domil, A. E., Puscas, A., Domil, M., Gencia, A., Ed. by Soliman, K.S. (2015, May) The Role of Accounting Information for a Sustainable Development within Farming Entities in Romania Case Study Banat Region. Innovation Vision 2020: From Regional Development Sustainability to Global Economic Growth, vol. 1-6, pp. 1655-1665. Conference - Conference: 25th International-Business-Information-Management-Association Conference - Location: Amsterdam, Netherlands -Date: MAY 07-08, 2015

Carter, A. J., Burritt, R. L., Pisaniello, J. D. (2013). Accountants as Emotional Wellbeing Counsellors in Rural Areas. Australian Accounting Review, vol. 23, no. 2. 151-162. doi:10.1111/auar.12007

Carter, C., Spence, C., Muzio, D. (2015). Scoping an agenda for future research into the professions. Accounting Auditing \& Accountability Journal, vol. 28, no. 8, pp. 1198-1216. doi: 10.1108/AAAJ-09-2015-2235 
Chan, C. C. A., Monroe, G. S., Ng, J., Tan, R. C. W. (2008). Effects of Employee Support on Junior Accountants' Job Attitudes and Intention to Quit. Australian Accounting Review, vol. 18, no. 2. 149-162. doi:10.1111/j.1835-2561.2008.0016.x

Clayton, B. M., van Staden, C. J. (2015). The Impact of Social Influence Pressure on the Ethical Decision Making of Professional Accountants: Australian and New Zealand Evidence. Australian Accounting Review, vol. 25, no. 4, pp. 372-388. doi: 10.1111/auar.12077

Davenport, L., Dellaportas, S. (2009). Interpreting the Public Interest: A Survey of Professional Accountants. Australian Accounting Review, vol. 19, no. 1, pp. 11-23. doi:10.1111/j.1835-2561.2008.00041.x

Gendron, Y., Suddaby, R., Sandy Q. (2009). Professional-Organisational Commitment: A Study of Canadian Professional Accountants. Australian Accounting Review, vol. 19, no. 3, pp. 231-248. doi: 10.1111/j.1835-2561.2009.00060.x

Guthrie, J., Parker, L. D. (2016). Whither the accounting profession, accountants and accounting researchers? Commentary and projections. Accounting Auditing \& Accountability Journal, vol. 29, no. 1, pp. 2-10. doi: 10.1108/AAAJ-10-2015-2263

The Institute of Chartered Accountants in England and Wales - ICAEW. Roles of Accountants.

Available on-line at www.icaew.com/en/technical/sustainability/getting-started/role-ofaccountants (13.09.2016)

International Federation of Accountants. Code of Ethics for Professional Accountants.

Available on-line at www.ifac.org/system/files/publications/files/ifac-code-of-ethics-for.pdf (05.09.2016)

The Accountancy Profession and the Sustainable Development Goals. International Federation of Accountants.

Available on-line at www.ifac.org/news-events/2015-11/accountancy-profession-andsustainable-development-goals (05.09.2016).

Lovell, H., MacKenzie, D. (2011). Accounting for Carbon: The Role of Accounting Professional Organisations in Governing Climate Change. Antipode, vol. 43, no. 3, pp. 704730. doi:10.1111/j.1467-8330.2011.00883.x

Luts, S. (2016). Raamatupidajate ja firmajuhtide hinnangud raamatupidajate pädevusele. Raamatupidamise Praktik, vol. 107, pp. 12-14.

Nwobu, O., Owolabi, A., Iyoha, F. Ed. Chova, L. G; Martinez, A. L, Torres, I. C. (2015). Sustainability Reporting and Professional Accounting Curriculum in Nigeria. ICERI2015 Conference: 8th International Conference of Education, Research and Innovation (ICERI).

Ottoson, E. (2015). Raamatupidaja roll Eesti ettevõttes. The Role of an Accountant in Estonian Company (Master Thesis). Tallinn: TUT Department of Accounting.

Available on-line at http://digi.lib.ttu.ee/i/?3292

Spraakman, G., O’Grady, W., Askarany, D., Akroyd, C. (2015). Employers' Perceptions of Information Technology Competency Requirements for Management Accounting Graduates. Accounting Education, vol. 24, no. 5, pp. 403-422. doi: 10.1080/09639284.2015.1089177

Yuan, S. Y., Lou, Y. Ed. Shaw, P. (2015, April). Study on Reform of Accounting Education Mode of Higher Vocational Schools Based on Training in High-Caliber Professional Accountants. Proceedings of the 2015 International Conference on Education Reform and Modern Management (ERMM 2015). Advances in Social Science Education and Humanities Research, vol. 15, pp. 5-8. 